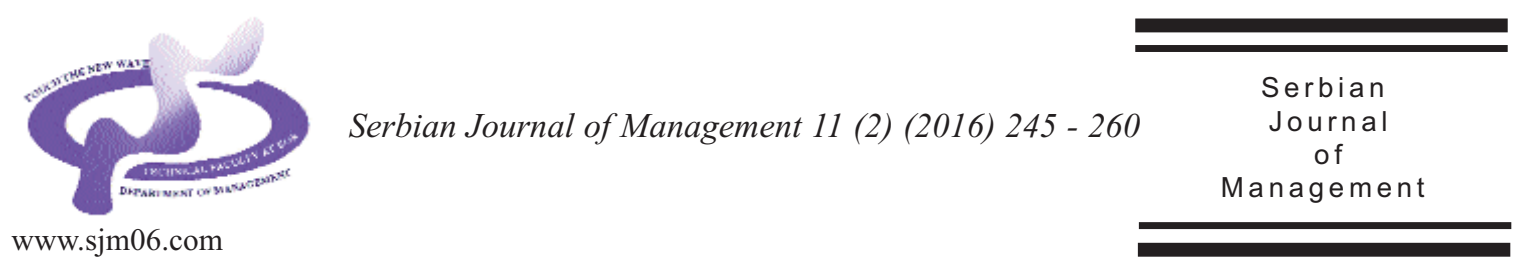

\title{
SUSTAINABILITY REPORTING QUALITY OF INDIAN AND AMERICAN MANUFACTURING FIRMS: A COMPARATIVE ANALYSIS
}

\author{
Diganta Munshi ${ }^{\mathrm{a}}$ and Sraboni Dutta ${ }^{b^{*}}$

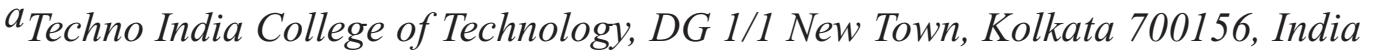

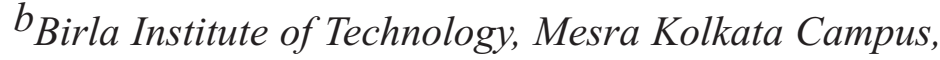 \\ 1582 Rajdanga main road, Kolkata 700107, India
}

(Received 24 November 2015; accepted 22 June 2016)

\begin{abstract}
The content analysis method has been adopted to study the pattern of reporting on sustainability indicators by 10 American and 10 Indian manufacturing firms in their sustainability reports prepared as per the GRI framework and published during 2011-2013. Scores of 2, 1 and 0 have been respectively assigned for full, partial and non disclosure of sub clauses of economic, environment and social indicators to compute a SDI (sustainability disclosure index). Independent $t$ test found a significant difference in the quality of sustainability disclosure of the sampled American and Indian manufacturing firms during 2011-13. The improvement/ deterioration in the quality of disclosure over the period were correlated with changes in performance parameters like EPS and ROA to examine if betterment in quality of sustainability reporting translates into financial performance of the firms. Multiple regression analysis was performed to determine the variables which explain the variation in the sustainability reporting quality of firms.
\end{abstract}

Keywords: Sustainability reporting quality, content analysis, disclosure index, financial performance, manufacturing firms

\section{INTRODUCTION}

Sustainability reporting is a practice adopted by firms for being accountable to its internal and external stakeholders. The reporting process entails measurement and thereafter a structured disclosure of firms' performance in the arena of sustainability, as per some guidelines followed globally. The sustainability reports provide information on the firms' efforts in the environmental, economic and social fields and has evolved

\footnotetext{
* Corresponding author: sdutta@bitmesra.ac.in

DOI:10.5937/sjm11-9593
} 
as a valuable tool of influencing stakeholders' perceptions about the firm's operations. Without a structured framework for sustainability reporting, there exists a risk of bias in the firms' reporting exercise and more importantly makes it difficult to compare their sustainability activities. Worldwide, the Global Reporting Initiative (GRI) Guidelines have emerged as the most widely acceptable sustainability reporting framework, followed by firms. It enables firms to report on numerous dimensions namely, economic, environment, society, human rights, labor practice, decent work and product responsibility Isa (2014).

Research shows that the technique of content analysis has been successfully applied to analyze firms' annual financial reports, corporate social responsibility reports, reports on corporate governance and other business documents and gather information about the firms (Bice, 2014). Content analysis is a systematic and scientific study of content communication which involves examining the content contained in reports / messages with reference to countable elements such as themes, paragraphs, words, concepts and characters (Prasad, 2008). In this paper, the content analysis approach has been adopted to gain insight about the pattern of disclosure made by American and Indian manufacturing firms in their sustainability reports, using the GRI Guidelines.

The research work have focused on manufacturing firms since sustainable business practices assume more significance for them compared to their counterparts in the service sector. The manufacturing firms engage in greater competition for usage of scarce natural resources, thereby leading to their depletion. Moreover, they being more polluting in nature than service oriented businesses, display significantly more concern towards environmental aspects such as reducing global warming and carbon footprint. This may be also due to stronger environmental regulations and requirements. Moreover, unwanted by-products or disposal of defective products by manufacturing firms, create an adverse effect on the society and consumer. A paradigm shift towards corporate sustainability, is forcing manufacturing firms across the globe to adopt alternative materials and lean manufacturing techniques to produce green products (Marwah et al., 2014).

For a considerable period of time, manufacturing firms in developed countries like USA, Europe, Japan, Australia and Germany have been supporting the context of sustainability due to their consciousness towards the environment and society (Daizy \& Das 2014). They have systematically adopted established frameworks for reporting their efforts towards upholding sustainability since the '90s. With the forces of globalization gaining in prominence, it has become imperative for Indian manufacturing firms to also concentrate on this issue of sustainability, which translates into a better image for them in the global scenario and ensures them long term success. The Indian firms need to adopt reporting guidelines like that of GRI, which are acceptable globally. Though Indian manufacturing firms have started sustainability reporting as per the GRI guidelines over the recent past, it needs to be examined if these firms from a developing country like India are at par with the firms from a developed nation like USA as far as their reporting quality is concerned. 


\section{LITERATURE REVIEW}

A firm's long term success, viability and growth will depend on the functioning of its communication system. Internal and external stakeholders are all vital viewers of the firm's sustainability report. Such a report can provide important information which becomes instrumental in elevating consciousness about improving the quality of life for all concerned stakeholders.

Dincer (2011) conducted a study on 92 firms listed on Istambul Stock Exchange, based on the framework proposed by Ullman (1985) and it was observed that publishing of CSR report is due to the considerable influence exerted by the government and creditors. It was also noted that financial institutions and shareholders are concerned with the financial performance of the firm, and not so much in its sustainable strategies or activities.

Content analysis method was adopted by Bayound et al. (2012) to examine the annual reports of 40 Libyan firms during 2007 2009. They assessed the relationship between firm reputation and level of the corporate social responsibility disclosure (CSRD), through a scoring index, where 1 or 0 score was allotted against disclosed or nondisclosed categories respectively. It was found that at $1 \%$ level of significance, a positive relationship exists between level of CSRD and firm reputation. Ching et al. (2013) studied 60 listed firms in Brazil comprising of top 36 sustainable firms and 24 conforming to corporate governance practice, in the year 2011. The aim of the study was to assess the quality of information disclosed by firms on sustainability dimensions. Content analysis was adopted for qualitative assessment and statistical analysis was employed for quantitative evaluation. After evaluating sustainability dimensions reported in sustainability reports, the firms were awarded a score ranging between 0 and 1, with 0 denoting the worst and 1 denoting the best score. Statistical analysis confirmed that the sustainable firms were disclosing more information and in a more satisfactory manner as compared to the firms adhering to corporate governance. Focusing on Indian firms, Mitra (2012) found that the absence of legal binding and lack of awareness amongst stakeholders have till now lead to lesser number of Indian enterprises publishing structured sustainability reports. However, he also highlighted that the sustainability reporting practices in India are gaining in focus and suggested that Indian firms will have to address a wide range of sustainability issues in their reports, given the growing concern for environment and community worldwide.

Academic attention has also been given towards finding a relationship between sustainability disclosures and economic performance parameters in firms. Study of 58 publicly listed Indonesian firms during 2010-12 by Kusuma and Koesrindartoto (2014), revealed that a positive relationship exists between sustainability disclosure and various financial performance parameters like return on asset, return on equity, return on invested capital, EBITDA margin, depreciation, amortization margin and net operating profit less adjusted taxes margin. A scoring methodology was adopted to formulate sustainability disclosure score, where 0 (zero) was awarded against the nondisclosure of a particular indicator and 1 (one) was awarded against the disclosure of a particular indicator. They concluded that a slightly positive but not very significant relationship exists between the sustainability 
disclosure score and financial performance. Burhan and Rahmanti (2012) studied 32 Indonesian firms during 2006-2009 to scrutinize the relationship between their performance and the nature of sustainability reporting in totality, as well as each of the components of sustainability reporting i.e. economic, environmental and social. They found that firm's ROA, a proxy measure of financial performance, is positively affected by sustainability reporting as a whole as well as by the disclosure of economic and environment performance parameters. However, social performance disclosure does not have any noteworthy influence on firm's ROA. Makori (2013) examined whether any relationship exists between profitability of the firm and environmental accounting of 14 firms, listed on the Bombay Stock Exchange. The study revealed that a negative relationship exists between environmental accounting and financial parameters like return on capital employed (ROCE) and earnings per share (EPS). However, the relationship is positive when environmental accounting is compared with net profit margin and dividend per share. It was further suggested by the author that government rules and regulations should be stringent for firms to comply with environmental laws and hence reporting environmental indicators should be made compulsory to enhance performance of the firms.

Prior research on sustainability reporting also focuses on firm specific variables which might impact the quality of disclosure. It has been established by Isa (2014), Aljifri et al. (2014), Yao et al. (2011) and Ali and Atan (2013) that size of the firm as proxied by measures such as total assets, market capitalization, net sales or number of employees is an influential variable in determining the sustainability disclosure practices amongst firms. This implies that a positive association exists between firm size and the extent of disclosure whereby larger firms tend to pay more attention towards quality of disclosures as compared to their smaller counterparts. Focusing on the firm's liquidity, Wallace et al. (1994), Aljifri et al. (2014) highlighted that firms with high liquidity ratio are more keen towards financial disclosure. Profitability of the firm as measured by indicators such as net income, profit margin, return on assets, and return on equity are associated with disclosure of sustainability parameters as evident in a study by Artiach et al. (2010). The age of the firm has some relationship with disclosure on sustainability parameters. It has been reported by Parsa and Kouhy (2008) that younger firms in comparison with older firms are not very enthusiastic in terms of disclosure on social parameters, due to lack of issues addressed. However, Yao et al. (2011) identified that in order to attract investors, newer firms are eager to disclose more information on social issues. Studies by Ali and Atan (2013), Michelon and Parbonetti (2012), Haniffa and Cooke (2005) have highlighted how some corporate governance variables such as size of the board of directors, board independence and CEO duality have an effect on the quality of disclosure. Review of available literature shows that location of a firm may be a determinant of sustainability disclosure. As posited by Van der Laan Smith et al. (2005), firms in countries with greater importance on social issues and additional focus on multi stakeholders, will display stronger and improved quality of social disclosure, as compared with firms originating in countries with lesser focus on social issues and more influence exerted by shareholders. Millar et 
al. (2005) stated that the high degree of disclosure is associated with Anglo-Saxon business systems in countries such as USA, UK, Canada vis-a vis the Communitarian system as in Germany France and Switzerland, where there is a tendency to disclose limited information due to prevalent lack of transparency. Taking the case of Czech Republic and Romania in the domain of environmental reporting, Jindrichovska and Purcărea (2011), suggested, that nonprescriptive approach which is prevalent in other developed countries, should be adopted in Czech Republic whereas for Romania a systematic and regulatory procedure should be followed. This review prompted us to design a model whereby the above mentioned firm specific variables have been included as independent variables to examine their effect on quality of sustainability reporting.

\section{OBJECTIVE}

The objective of this study is to determine:

a) The ranks of the Indian and American firms as per their sustainability disclosure index and make comparisons thereof.

b) The improvement / deterioration in the quality of sustainability reporting, between 2011-12 and 2012-13 by noting the changes in the year-wise ranks assigned.

c) If the reporting quality in the sustainability reports of American and Indian manufacturing firms differed significantly over the said period, using the independent $t$ test.

d) Whether the change in the sustainability reporting quality (as proxied by sustainability disclosure index) has any correlation with change in the financial parameters of the firms (as proxied by EPS and ROA) over the said period.

e) The extent to which independent variables such as total assets, firm age, liquidity, profitability, board composition, board independence, CEO duality and lastly location of the firm contribute significantly towards explaining the variation in the dependent variable i.e. quality of sustainability reporting (as proxied by sustainability disclosure index).

\section{METHODOLOGY}

\subsection{Database}

Data and facts have been collected from the Annual Reports and Sustainability Reports published by Indian and American manufacturing companies. The profile of the firms is in Table 1. Out of 40 manufacturing companies listed in the Nifty, of the National Stock Exchange in India only 10 firms have published sustainability reports for the financial years 2011 - 2012 and 2012 - 2013, as per the Global Reporting Initiative framework. Hence all these 10 firms have been included in the study. The sample consists of 3 public sector units (PSUs') namely Gail (India) Limited, Oil and Natural Gas Corporation Limited, Bharat Petroleum Corporation Limited and 7 private sector firms like Tata Steel Limited, Tata Motors Limited, ITC Limited, Hindalco Industries Limited, Reliance Industries Limited, Mahindra \& Mahindra Limited, Larsen \& Toubro Limited.

In order to maintain parity and undertake meaningful comparison with these Indian manufacturing firms, we decided to consider 10 American manufacturing firms listed on the NASDAQ. Out of 5519 American firms 
Table 1. Profile of Firms

\begin{tabular}{|c|c|c|c|c|}
\hline INDIAN FIRMS & AGE & $\begin{array}{l}\text { NET INCOME } \\
\text { OF YR 12-13 IN } \\
\text { US \$ MILLION }\end{array}$ & $\begin{array}{c}\text { SALES OF } \\
\text { YR12-13 IN } \\
\text { US \$ } \\
\text { MILLION }\end{array}$ & INDUSTRY \\
\hline ITC Limited & 41 & 7418.39 & 30839.97 & Tobacco \\
\hline Larsen \& Toubro Limited & 65 & 4910.65 & 62724.16 & Engineering \\
\hline Reliance Industries Limited & 30 & 21003 & 368295 & Oil and Gas \\
\hline Tata Steel Limited & 108 & 5062.97 & 39101.47 & Metals and Mining \\
\hline Tata Motors Limited & 70 & 301.81 & 46853.92 & Automotives \\
\hline $\begin{array}{l}\text { Oil and Natural Gas Corporation } \\
\text { Limited }\end{array}$ & 59 & 88442.07 & 20925.69 & Oil and Gas \\
\hline Gail (India) Limited & 31 & 4022.20 & 48287.2 & Oil and Gas \\
\hline Hindalco Industries Limited & 57 & 1669.20 & 27040.02 & Metals and Mining \\
\hline $\begin{array}{l}\text { Bharat Petroleum Corporation } \\
\text { Limited }\end{array}$ & 38 & 2642.90 & 241795.98 & Oil and Gas \\
\hline Mahindra \& Mahindra Limited & 67 & 4099.20 & 69142.60 & Automotives \\
\hline AMERICAN FIRMS & AGE & $\begin{array}{c}\text { SALES OF } \\
\text { YR12-13 IN US \$ } \\
\text { MILLION }\end{array}$ & $\begin{array}{c}\text { NET } \\
\text { INCOME } \\
\text { OF YR 12- } \\
13 \text { IN US \$ } \\
\text { MILLION } \\
\end{array}$ & INDUSTRY \\
\hline 3M Company & 86 & 30900 & 4721 & Health care \\
\hline The Coca Cola Company & 86 & 46854 & 8626 & Consumer non durables \\
\hline Colgate & 92 & 17420 & 2410 & Consumer non durables \\
\hline The Dow Chemical Company & 68 & 57080 & 4816 & Basic industry \\
\hline DuPont & 213 & 35700 & 4862 & Basic industry \\
\hline General Motors Company & 107 & 155427 & 5331 & Capital goods \\
\hline Intel Corporation & 47 & 52700 & 9620 & Technology \\
\hline Johnson \& Johnson & 128 & 13831 & 13831 & Health care \\
\hline Norfolk Southern Corporation & 35 & 11245 & 1910 & Transportation \\
\hline The Procter \& Gamble Company & 110 & 53900 & 11402 & Basic industry \\
\hline
\end{tabular}

listed on NASDAQ, the random sampling technique was used to select 10 manufacturing firms namely, 3M Company, The Coca Cola Company, Colgate, The Dow Chemical Company, DuPont, General Motors Company, Intel Corporation, Johnson \& Johnson, Norkfolk Southern Corporation, and The Procter \& Gamble Company.

\subsection{Computation of Sustainability} Disclosure Index

According to GRI (Global Reporting Initiative) framework, there are 3 sustainability indicators namely i) economic ii) environment and iii) social, comprising of 9, 30 and 45 sub clauses respectively, on which reporting is required. The content 
analysis approach was used to examine the nature of reporting by the sampled Indian and American firms on each of the sub clauses of all 3 sustainability indicators, as the unit of our count. The content on the disclosure made, was studied and a scoring system was devised to reflect the quality of the disclosures.

Firms which have fully reported against a particular sub-clause of economic, environment or social indicator of the GRI framework, have been awarded 2 points. Likewise for partial reporting and for non reporting against a particular sub-clause, 1 and 0 points have been awarded respectively. This procedure has been followed for each of the 2 financial years (2011-12 \& 2012-13).

For each financial year, the scores assigned to the component sub clauses of an indicator (economic / environment / social) were summated to find the total disclosure score, $\left(\mathrm{TD}_{\mathrm{i}}\right)$ and then divided by the maximum score possible $\left(\mathrm{M}_{\mathrm{i}}\right)$, to compute the disclosure index of that indicator $\left(\mathrm{DI}_{\mathrm{i}}\right)$ as given below.

The total disclosure score $\left(\mathrm{TD}_{\mathrm{i}}\right)$ for a sustainability indicator $\mathrm{i}$ was calculated as follows:

$$
\mathrm{TD}_{\mathrm{i}}=\sum_{\mathrm{s}=1}^{\mathrm{n}} \mathrm{d}_{\mathrm{s}}
$$

Where $d_{s}$

$=2$ for full reporting against a sub clause $\mathrm{s}$

$=1$ for partial reporting against a sub clause $\mathrm{s}$

$=0$ for non reporting against a sub clause $\mathrm{s}$ and

$\mathrm{n}=9$ for $\mathrm{i}=$ economic indicator

$\mathrm{n}=30$ for $\mathrm{i}=$ environment indicator

$\mathrm{n}=45$ for $\mathrm{i}=$ social indicator

Maximum possible score is $" \mathrm{M}_{\mathrm{i}}=2 \mathrm{n}_{\mathrm{i}}{ }^{\prime}$ considering that full reporting has been done on all clauses of the said indicator $i$.

Disclosure Index: $\mathrm{DI}_{\mathrm{i}}=\mathrm{TD}_{\mathrm{i}} / \mathrm{M}$

The sustainability disclosure index (SDI) for each firm was therefore calculated by summating the total disclosure score $\left(\mathrm{TD}_{\mathrm{i}}\right)$ of all 3 indicators, and then dividing the score with the maximum score possible i.e. 168 considering that full reporting has been done on all clauses of all the 3 indicators.

$$
\mathrm{SDI}=\sum \mathrm{TD}_{\mathrm{i}} / 168
$$

For instance, in the year 2011-12, for The Dow Chemical Company, total disclosure score in economic indicator $\left(\mathrm{TD}_{\text {eco }}\right)$ was 17 for the 9 sub clauses in the said indicator. $\left(\mathrm{M}_{\mathrm{eco}}\right)$ being 18, the $\left(\mathrm{DI}_{\text {eco }}\right)$ was computed as 0.94. Similarly $\left(\mathrm{TD}_{\text {env }}\right)$ and $\left(\mathrm{TD}_{\text {soc }}\right)$ scores were 54 and 80 respectively. Thus (SDI) for The Dow Chemical Company in the year 2011-12 was calculated as $(17+54+80) / 168=$ 0.90 This exercise was repeated for the next year, and thereafter the average disclosure index for 2011-13 corresponding to each indicator was computed. To capture the sustainability disclosure quality in totality for the 2 year period, the average sustainability disclosure index (SDI) was calculated.

\section{DATA ANALYSIS AND DISCUSSION}

\subsection{Ranks based on Sustainability Disclosure Indices during 2011-13}

Table 2 shows the ranks assigned to the American and Indian firms as per their average sustainability disclosure index generated for the period 2011-13. Dow Chemical Company has been ranked $1^{\text {st }}$ amongst the 10 firms, and it may be noted that it secures the $1^{\text {st }}$ position in the 
economic, environmental and social fields as well. Intel Corporation and Johnson \& Johnson have attained $2^{\text {nd }}$ and $3^{\text {rd }}$ position respectively. It may be interesting to note that although Johnson and Johnson have reported well on the social and economic indicators, it has considerably lagged behind when reporting on environmental aspects. This indicates that the firm has not given equal importance towards reporting on all the three aspects of sustainability. The Coca Cola Company has been ranked last amongst the 10 firms. Amongst the Indian manufacturing companies, Tata Steel Limited has been ranked $1^{\text {st }}$, on the basis of its average sustainability disclosure index. It is followed closely by Reliance Industries Limited and Oil and Natural Gas Corporation Limited. Larsen and Toubro did not assign equal importance towards all three different parameters of sustainability reporting. The quality of reporting on environmental parameters was poor, in comparison to economic and social reporting. ITC limited has been ranked last amongst the 10 Indian firms.

Table 2. Ranks based on Sustainability Disclosure Indices for 2011-13

\begin{tabular}{|c|c|c|c|c|c|c|}
\hline & FIRM NAME & D $I_{\text {eco }}$ & D $I_{\text {env }}$ & D $I_{\text {soc }}$ & SDI & $\begin{array}{c}\text { RANK BASED ON } \\
\text { SUSTAINABILITY } \\
\text { INDEX }\end{array}$ \\
\hline \multirow{10}{*}{ 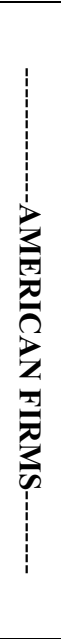 } & $\begin{array}{l}\text { The Coca Cola } \\
\text { Company }\end{array}$ & 0.44 & 0.36 & 0.27 & 0.32 & 10 \\
\hline & $\begin{array}{l}\text { Norfolk Southern } \\
\text { Corporation }\end{array}$ & 0.42 & 0.58 & 0.26 & 0.39 & 9 \\
\hline & $\begin{array}{l}\text { General Motors } \\
\text { Company }\end{array}$ & 0.44 & 0.63 & 0.28 & 0.43 & 8 \\
\hline & 3M Company & 0.61 & 0.47 & 0.44 & 0.47 & 7 \\
\hline & DuPont & 0.47 & 0.55 & 0.49 & 0.51 & 6 \\
\hline & Colgate & 0.44 & 0.65 & 0.54 & 0.57 & 5 \\
\hline & $\begin{array}{l}\text { The Procter \& } \\
\text { Gamble Company }\end{array}$ & 0.89 & 0.80 & 0.60 & 0.7 & 4 \\
\hline & Johnson \& Johnson & 0.72 & 0.59 & 0.79 & 0.71 & 3 \\
\hline & Intel Corporation & 0.78 & 0.77 & 0.69 & 0.73 & 2 \\
\hline & $\begin{array}{l}\text { The Dow Chemical } \\
\text { Company }\end{array}$ & 0.97 & 0.93 & 0.93 & 0.93 & 1 \\
\hline \multirow{10}{*}{ 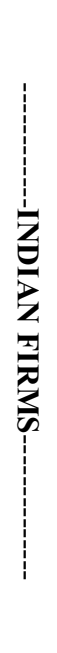 } & ITC Limited & 0.78 & 0.67 & 0.52 & 0.6 & 9 \\
\hline & $\begin{array}{l}\text { Bharat Petroleum } \\
\text { Corporation Limited }\end{array}$ & 0.81 & 0.68 & 0.64 & 0.67 & 8 \\
\hline & $\begin{array}{l}\text { Hindalco Industries } \\
\text { Limited }\end{array}$ & 0.83 & 0.65 & 0.71 & 0.7 & 7 \\
\hline & $\begin{array}{l}\text { Mahindra \& } \\
\text { Mahindra Limited }\end{array}$ & 0.78 & 0.75 & 0.73 & 0.74 & 6 \\
\hline & Gail (India) Limited & 0.61 & 0.66 & 0.87 & 0.76 & 5 \\
\hline & $\begin{array}{l}\text { Larsen \& Toubro } \\
\text { Limited }\end{array}$ & 1.00 & 0.62 & 0.82 & 0.77 & 4 \\
\hline & Tata Motors Limited & 0.50 & 0.88 & 0.91 & 0.85 & 3 \\
\hline & $\begin{array}{l}\text { Oil and Natural Gas } \\
\text { Corporation Limited }\end{array}$ & 1.00 & 0.85 & 0.89 & 0.89 & 2 \\
\hline & $\begin{array}{l}\text { Reliance Industries } \\
\text { Limited }\end{array}$ & 0.94 & 0.92 & 0.97 & 0.95 & 1 \\
\hline & Tata Steel Limited & 0.94 & 0.97 & 0.94 & 0.95 & 1 \\
\hline
\end{tabular}


5.2. Improvement / detoriation in the Corporation and Norfolk Southern quality of disclosure on sustainability Corporation have been able to improve their indicators pattern of disclosure in 2012-13 as compared to 2011-12. Comparatively the change has

In Table 3 we compare the ranks attained by the sampled firms in 2012-13 with that of 2011-12 to highlight any improvement /deterioration in the quality of disclosures on sustainability indicators. 6 firms namely $3 \mathrm{M}$ Company, The Coca Cola Company, been more phenomenal in case of DuPont, General Motors Company and Intel Corporation. Colgate, Dow Chemical Company and The Procter and Gamble Company have been able to maintain the DuPont, General Motors Company, Intel Johnson phenomenal detoriation has taken

Table 3. Detoriation / Improvement in quality of sustainability disclosure in 2012-13 vs 2011-12

\begin{tabular}{|c|c|c|c|c|c|c|c|c|c|}
\hline & FIRM NAME & ECOI & MIC & ENVIR & MENT & SOC & & SUSTA & BILITY \\
\hline & & & & & & RAI & & & \\
\hline & FIRMS & $\begin{array}{c}\mathrm{YR} \\
11-12\end{array}$ & $\begin{array}{c}\mathrm{YR} \\
12-13 \\
\end{array}$ & $\begin{array}{c}\mathrm{YR} \\
11-12\end{array}$ & $\begin{array}{c}\mathrm{YR} \\
12-13\end{array}$ & $\begin{array}{l}\text { YR 11- } \\
12\end{array}$ & $\begin{array}{c}\mathrm{YR} \\
12-13 \\
\end{array}$ & $\begin{array}{c}\mathrm{YR} \\
11-12\end{array}$ & $\begin{array}{c}\mathrm{YR} \\
12-13\end{array}$ \\
\hline & 3M Company & 5 & 4 & 8 & 6 & 6 & 6 & 9 & 5 \\
\hline & $\begin{array}{l}\text { The Coca Cola } \\
\text { Company }\end{array}$ & 7 & 6 & 9 & 7 & 9 & 8 & 10 & 7 \\
\hline & Colgate & 7 & 6 & 5 & 4 & 4 & 6 & 5 & 5 \\
\hline 정 & $\begin{array}{l}\text { The Dow Chemical } \\
\text { Company }\end{array}$ & 1 & 1 & 1 & 1 & 1 & 1 & 1 & 1 \\
\hline 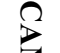 & DuPont & 6 & 5 & 8 & 4 & 8 & 4 & 8 & 4 \\
\hline$\underline{Z}$ & $\begin{array}{l}\text { General Motors } \\
\text { Company }\end{array}$ & 4 & 7 & 7 & 3 & 7 & 9 & 6 & 3 \\
\hline 3 & Intel Corporation & 3 & 3 & 4 & 2 & 3 & 3 & 4 & 2 \\
\hline & Johnson \& Johnson & 6 & 2 & 2 & 8 & 2 & 2 & 3 & 6 \\
\hline & $\begin{array}{l}\text { Norfolk Southern } \\
\text { Corporation }\end{array}$ & 8 & 6 & 6 & 5 & 10 & 7 & 7 & 5 \\
\hline & $\begin{array}{l}\text { The Procter \& } \\
\text { Gamble Company }\end{array}$ & 2 & 2 & 3 & 2 & 5 & 5 & 2 & 2 \\
\hline & ITC Limited & 3 & 4 & 6 & 5 & 9 & 10 & 8 & 6 \\
\hline & $\begin{array}{l}\text { Larsen \& Toubro } \\
\text { Limited }\end{array}$ & 1 & 1 & 7 & 7 & 5 & 5 & 7 & 7 \\
\hline & $\begin{array}{l}\text { Reliance Industries } \\
\text { Limited }\end{array}$ & 2 & 2 & 2 & 2 & 1 & 2 & 2 & 2 \\
\hline & Tata Steel Limited & 2 & 2 & 2 & 1 & 2 & 1 & 2 & 1 \\
\hline$\underline{Z}$ & $\begin{array}{l}\text { Tata Motors } \\
\text { Limited }\end{array}$ & 4 & 5 & 4 & 2 & 4 & 3 & 4 & 4 \\
\hline$\frac{1}{2}$ & $\begin{array}{l}\text { Oil and Natural Gas } \\
\text { Corporation }\end{array}$ & 1 & 1 & 3 & 3 & 3 & 4 & & \\
\hline$\underline{\Xi}$ & Limited & & & & & & & 3 & 3 \\
\hline$\frac{\pi}{3}$ & $\begin{array}{l}\text { Gail (India) } \\
\text { Limited }\end{array}$ & 1 & 6 & 1 & 9 & 1 & 7 & 1 & 9 \\
\hline & $\begin{array}{l}\text { Hindalco Industries } \\
\text { Limited }\end{array}$ & 4 & 2 & 6 & 6 & 6 & 8 & 9 & 5 \\
\hline & Bharat Petroleum & 4 & 3 & 5 & 8 & 8 & 9 & & \\
\hline & Limited & & & & & & & 6 & 8 \\
\hline & $\begin{array}{l}\text { Mahindra \& } \\
\text { Mahindra Limited }\end{array}$ & 3 & 4 & 5 & 4 & 7 & 6 & 5 & 5 \\
\hline
\end{tabular}


place from $3^{\text {rd }}$ position to $6^{\text {th }}$ position due to lesser disclosure on the environmental clause. It has been observed that 3 Indian manufacturing firms namely ITC Limited, Tata Steel Limited and Hindalco Industries Limited have bettered their sustainability reporting quality in 2012-13 as compared to 2011-12. Larsen \& Toubro Limited, Reliance Industries Limited, Tata Motors Limited, Oil and Natural Gas Corporation Limited and Mahindra \& Mahindra Limited have been able to maintain the same the same rank during the period 2012-13 when compared with 2011-12. There has been significant deterioration in the sustainability reporting quality of Gail (India) Limited which secured the $1^{\text {st }}$ rank in 2011-12, but scored $9^{\text {th }}$ in 2012-13. The firm did not report on numerous clauses of the 3 sustainability indicators in 2012-13.

\section{3. t-Test for comparing American and Indian firms' reporting quality}

The independent $t$ test was performed by using IBM SPSS version 20.0, to examine if the sustainability disclosure index of the sampled American and Indian manufacturing firms for the period 2011-13, differed significantly. In addition, $t$ tests were also conducted for judging the difference in the extent of disclosures on economic, environment and social indicators individually. Prior to conducting the $t$ tests the Shapiro-Wilk Test was undertaken to test the data for normality. Corresponding to all the 4 variables of interest i.e. disclosure index on economic, environment, social and sustainability indicators for both American and Indian companies respectively, the significance value of the Shapiro-Wilk Test was greater than 0.05 , suggesting that the data is normal.
The results of the independent t-tests for the overall sustainability disclosure index, indicated that there is a significant difference in the quality of disclosures made by the sampled American and Indian firms in their sustainability reports. It is evident that that the Indian firms (mean=0.7880) have scored better than their American counterparts $($ mean $=0.5760)(t=-3.01)(\mathrm{Sig}=0.008)$. It implies that the Indian firms are more diligent than the American firms with respect to providing full disclosure on various clauses of sustainability indicators. Similar results are observed when the disclosure indices for economic, environment and social indicators of the 2 groups of firms are compared. While the results are significant at $p<0.05$ for the economic and social indicators, for the environment indicator the results are significant at $p<0.1$ as shown in Table 4.

It needs to reiterate that this study merely highlights the difference in the pattern of sustainability reporting of the sampled American and Indian firms. It in no way posits that American firms take less effort at upholding sustainability initiatives when compared to its Indian counterparts since that is beyond the purview of this study.

\subsection{Correlation between financial performance parameters and sustainability disclosure index}

Literature review establishes evidence of relationship between sustainability initiatives and financial performance. In this study, proportionate change in financial parameters like EPS and ROA between 2011-12 and 2012-13 has been computed and thereafter correlated with the proportionate change in sustainability disclosure index over the 2 year period. In case of American 
Table 4. $t$ test for difference in sustainability disclosure quality of American and Indian firms

\begin{tabular}{|c|c|c|c|c|}
\hline Indicator & Nation & Mean & t Value & Significance \\
\hline \multirow[t]{2}{*}{ ECONOMIC } & AMERICAN FIRM & .6180 & -2.394 & $.028 * *$ \\
\hline & INDIAN FIRM & .8190 & & \\
\hline ENVIRONMENT & $\begin{array}{l}\text { AMERICAN FIRM } \\
\text { INDIAN FIRM }\end{array}$ & $\begin{array}{l}.6330 \\
.7650\end{array}$ & -1.990 & $.062 *$ \\
\hline SOCIAL & $\begin{array}{l}\text { AMERICAN FIRM } \\
\text { INDIAN FIRM }\end{array}$ & $\begin{array}{l}.5290 \\
.8000\end{array}$ & -3.160 & $.005 * *$ \\
\hline SUSTAINABILITY & $\begin{array}{l}\text { AMERICAN FIRM } \\
\text { INDIAN FIRM }\end{array}$ & $\begin{array}{l}.5760 \\
.7880\end{array}$ & -3.010 & $.008 * * *$ \\
\hline
\end{tabular}

firms, the Pearson's correlation coefficient between change in sustainability disclosure index and change in EPS is 0.135 , while it is 0.315 in case of change in ROA. The results indicate that there is a weak and positive correlation between the change in the quality of sustainability reporting and the change in the financial performance parameters during the period. The results were similar for Indian firms, and the Pearson's correlation coefficient between change in sustainability disclosure index and change in EPS and ROA was 0.377 and 0.142 respectively, as shown in Table 5 . The results however were not significant. This research fails to establish that betterment in the pattern of sustainability disclosure translates into better financial performance for the firms. This implies that engaging in better reporting is a voluntary action on the part of the corporate and not so much motivated by the prospects of bettering their bottom line.
5.5. Multiple Regression Analysis: Determinants of Sustainability Disclosure Index

Multiple regression analysis was conducted to identify variables which explain the variation in the sustainability reporting quality of firms. The sustainability disclosure index (SDI) was regressed against the 8 specified independent variables by applying the OLS regression procedures.

The regression model is expressed as follows:

$$
S D I=\alpha+\beta_{1} \text { Firm Size }+\beta_{2} \text { Firm Age }+\beta_{3}
$$
Liquidity $+\beta_{4} R O E+\beta_{5}$ Board Composition $+\beta_{6}$ Board Independence $+\beta_{7}$ CEO Duality $+\beta_{8}$ Location of the firms $+\varepsilon$

Where the variables are as follows:

Table 5. Correlation between proportionate change in sustainability disclosure index and proportionate change in EPS / ROA in 2012-13 vs 2011-12

\begin{tabular}{lccc}
\hline & & Change in EPS & Change in ROA \\
\hline American firms & Pearson Correlation & .135 & .315 \\
& Sig. (2 tailed) & .710 & .375 \\
Indian firms & Pearson Correlation & .377 & .142 \\
& Sig. (2 tailed) & .283 & .695 \\
\hline
\end{tabular}


Variables

Measurement

\section{Dependent:}

Sustainability Disclosure Index (SDI)

Unweighted Sustainability Disclosure Index

\section{Independent:}

Firm size

Firm age

Liquidity

ROE

Board composition

Directors independence

CEO duality

Location of firm
Natural logarithm of the average of total assets for 2011-13.

Age of firms since date of incorporation.

Current ratio for 2011-13.

Ratio of Net income to Shareholders Equity for 2011-13.

Average number of board members during 2011-13.

Average number of independent directors for 2011-13.

$1=$ Yes and $0=$ No.

$1=$ American firms, $0=$ Indian firms.
From the model summary of the results given in Table 6a, it is seen that the value of $\mathrm{R}$ is 0.877 . This denotes the high correlation between the observed sustainability disclosure index and the values predicted by the model. The coefficient of determination $\mathrm{R}^{2}$ equals to 0.77 Thus one may suggest that the 8 predictor variables of this model explain $77 \%$ of the variation in the sustainability disclosure index (SDI) (the dependent variable). The Adjusted $\mathrm{R}^{2}$ is 0.603 which reflects that the model fits the population well.

The significance of the overall regression, conducted by using an $\mathrm{F}$ statistic is determined by the $\mathrm{F}$ value ofs 4.60 which is significant at $1 \%$ level of significance. The significance of each of the predictor variables is displayed in Table $6 \mathrm{~b}$. The total assets of the firm and location of the firm are the only two predictor variables which are significant at $10 \%$ level of significance. The total assets are positively and significantly associated with the extent of disclosure of the sample companies. With respect to location of the firm, which is a dummy variable, the value of the partial regression coefficient, $b$, shows that American firms are less conscious about their quality of sustainability reporting as compared to their Indian counterparts (the referral category).

The model indicated that the other variables did not significantly affect the variations in the sustainability disclosure index (SDI) of the sample firms.

\section{CONCLUSION}

The Legitimacy Theory framework highlights the need for firms to conduct their activities in a manner which conforms to society's expectations (O'Donovan, 2002). The importance of sustainability reporting arises from this need to legitimize its actions since the information disclosed in the reports 
Table 6a. Model Summary on the robustness of Regression Analysis

\begin{tabular}{ccccc}
\hline Model & $\mathrm{R}$ & R Square & $\begin{array}{c}\text { Adjusted R } \\
\text { Square }\end{array}$ & $\begin{array}{c}\text { Std. Error of } \\
\text { the Estimate }\end{array}$ \\
\hline 1 & .877 & .770 & .603 & .11906 \\
\hline
\end{tabular}

Table 6b. Significance of the Partial Regression Coefficients

\begin{tabular}{llllll}
\hline \multirow{2}{*}{ Model } & \multicolumn{2}{l}{$\begin{array}{l}\text { Unstandardized } \\
\text { Coefficients }\end{array}$} & $\begin{array}{l}\text { Standardized } \\
\text { Coefficients }\end{array}$ & $\mathrm{t}$ & Sig. \\
\cline { 2 - 6 } & $\mathrm{B}$ & Std. Error & & & \\
\hline (Constant) & .575 & .464 & & 1.239 & .241 \\
Total Assets & .079 & .043 & .317 & 1.841 & .093 \\
Age of the firm & .000 & .001 & -.052 & -.302 & .768 \\
Liquidity & -.007 & .065 & -.019 & -.110 & .914 \\
ROE & -.010 & .011 & -.167 & -.944 & .365 \\
Board composition & -.030 & .027 & -.335 & -1.087 & .300 \\
Directors independence & -.024 & .024 & -.318 & -1.013 & .333 \\
CEO duality & .006 & .073 & .014 & .082 & .936 \\
Location of the firms & -.190 & .103 & -.515 & -1.840 & .093 \\
\hline
\end{tabular}

is instrumental in shaping society's perception towards the firm (Cho \& Patten, 2007). This study is a step towards evaluating the quality of the disclosure made by a sample of American and Indian manufacturing firms, via a proxy measure termed sustainability disclosure index (SDI).

On a scale of 0 to 1 , the mean SDI for American firms has been computed as 0.57 . In the sample of American firms it is found that $40 \%$ of the firms have SDI exceeding the mean. The ranking of firms on the basis of the SDI has enabled us to identify firms which are exemplary and can establish a benchmark for sustainability disclosure quality. One such firm is The Dow Chemical Company has been ranked 1 ${ }^{\text {st }}$ with a SDI of 0.93. Although the mean SDI of Indian firms being 0.788 , exceeds that of the American firms, it is interesting to note that in this case to $40 \%$ of the firms have SDI exceeding the mean. 2 firms namely Reliance Industries Limited and Tata Steel Limited have tied for the $1^{\text {st }}$ rank with a SDI value of 0 . This study is novel in highlighting that in this particular sample of 20 firms, the Indian manufacturing firm have emerged as being more conscious towards reporting sustainability indicators, in comparison to American manufacturing firms. These Indian firms are providing full disclosure on many clauses of the 3 indicators, namely economic, environment and social. The results of the Independent $t$ test also echoes that a significant difference exists in the quality of reporting of Indian firms in comparison to their American counterparts. However, this study in no way claims that the American firms take less effort at upholding sustainability initiatives when compared to its Indian counterparts. Examining the change in the SDI over the 2 year period, we observed that 6 American firms have successfully improved their quality of disclosure by providing complete information on more number of clauses of the sustainability indicators in 2012-13 vis-àvis 2011-12. However in the Indian sample only 3 firms have demonstrated improvement in SDI. Scrutiny of the change in the quality of sustainability reporting, 
between the 2 years enabled us to identify the firms whose reporting quality was showing a regressive trend, which calls for attention and action. It may be noted that for both group of firms, although a weak positive correlation exists between change in sustainability reporting quality and change in financial parameters like EPS and ROA over the 2 year span, the results are not significant. The multiple regression exercise established that contrary to prior research, in this study, the corporate governance variables like CEO duality, board composition and board independence failed to significantly explain the variation in the quality of sustainability disclosure. However, total assets and location of firms have emerged as significant determinants of the quality of sustainability disclosure in this study.

As with any research, this study has its limitations. One inadequacy of the study is that the sample size is small, spanning only 20 companies, 10 from each country. We have been unable to study more than 10 Indian manufacturing firms because these were the only listed firms which have been publishing sustainability reports as per GRI frame work during the 2 year period of our study i.e. 2011-13. Thereafter to maintain parity, the same number of American firms has been examined. The study only pertains to manufacturing firms and the service sector has not been examined although corporate sustainability is an issue of concern for all industries, irrespective of sector. The sample size as well as the time frame of study may be increased to improve the reliability of the results. Since this is a preliminary inquiry over a group of firms, this study provides us an indication of what may be expected from a larger sample.

As a way forward, this study can be extended to include firms in other countries such that a more robust cross-country comparison can be undertaken. This will highlight the extent of which location of a firm influences its quality of sustainability disclosure. Further, service sector industries may be brought under the purview of examination and a comparison between the manufacturing and service oriented firms may be undertaken to investigate if the industry sector is an important determinant of sustainability disclosure.

\section{References}

Artiach, T., Lee, D., Nelson, D., \& Walker, J. (2010). The determinants of corporate sustainability performance. Accounting and Finance, 50 (1), 31-51.

Ali, M.A.M., \& Atan, H.R. (2013). The relationship between corporate governance and corporate social responsibility disclosure: a case of high Malaysian sustainability companies and global sustainability companies. South East Asia Journal of Contemporary Business, Economics and law, 3 (1), 39-48.

Aljifri, K., Alzarouni, A., Ng, C., \& Tahir, M.I. (2014). The association between firm characteristics and corporate financial disclosures: evidence from UAE companies. The International Journal of Business and Finance Research, 8 (2), 101-123.

Burhan, A.H.N., \& Rahmanti, W. (2012). The impact of sustainability reporting on company performance. Journal of Economics Business and Accountancy Ventura, 15 (2), 257-272.

Bayound, N.S., Kavanagh, M., \& Slaughter, G. (2012). Corporate Social Responsibility Disclosure and Corporate Reputation in Developing countries: The 


\title{
КВАЛИТЕТ ИЗВЕШТАЈА ОДРЖИВОСТИ ПОСЛОВАЊА ИНДИЈСКИХ И АМЕРИЧКИХ КОМПАНИЈА: УПОРЕДНА АНАЛИЗА
}

\author{
Diganta Munshi, Sraboni Dutta
}

Извод

Да би се проучио начин извештавања индикатора одрживости пословања 10 америчких и 10 индијских производних компанија, коришћен је метод алаизе садржаја. Сами извештаји су припремљени у оквиру ГРИ оквира и званично публиковани у периоду 2011-2013

Како би се прорачунао СДИ (индекс показатеља одрживости), под-класе економских, еколошких и друштвених иникатора су оцењиване са 2 (потпуно), 1 (делимично) и 0 (непотпуно). Значајна разлика у квалитету приказа одрживости анализираних америчких и индијских производних компанија је установљена применом независног т - теста, за период 2011-13. Како би се установило да ли ће бољи квалитет извештавања одрживости резултовати бољим финансијским перформансама компанија, урађена је корелација фактора показатеља квалитета извештавања и показатеља перформанси пословања, као што су ЕПС и РОИ. Вишеструка регресиона анализа је коришћена да би се одредиле промењиве које објашњавају варијацију у квалитету изветавања одрживости компанија.

Кључне речи: Квалитет извештавања одрживости, анализа садржаја, индекс приказа, финансијске перформансе, производне компаније

study of Libya. Journal of Business and Policy Research, 7 (1), 131-160.

Bice, S. (2014). What Gives You a Social License? An Exploration of the Social License to Operate in the Australian Mining Industry, Resources, 3 (1), 62-80.

Ching, H.Y., Gerab, F., \& Toste, T. (2013).Analysis of Sustainability reports and Quality of Information disclosed of Top Brazilian Companies. International Business Research, 6 (10), 62-77.

Cho, C.H., \& Patten, D.M. (2007). The role of environmental disclosures as tools of legitimacy: A research note. Accounting, Organization and Society, 32 (7-8), 639-647.

Daizy, \& Das, N. (2014). Sustainability reporting framework: comparative analysis of global reporting initiatives and Dow Jones sustainability index. International Journal of Science, Environment and Technology, 3 (1), 55-66.

Dincer, B. (2011).Do the Shareholders Really Care about Corporate Social Responsibility. International Journal of Business and Social Science, 2 (10), 71-76.

Haniffa, R.M., \& Cooke, T.E. (2005). The impact of culture and corporate governance on corporate social reporting. Journal of Accounting and Public Policy, 24, 391-430.

Isa, M.A. (2014). Sustainability reporting among Nigeria Food and Beverages firm. International Journal of Agriculture and Economic Development, 2 (1), 1-9.

Jindrichovska, I., \& Purcărea, I. (2011). CSR and environmental reporting in the 
Czech Republic and Romania: country comparison of rules and practices. Accounting and Management Information Systems, 10 (2), 202-227.

Kusuma, A.P.A., \& Koesrindartoto, D.P. (2014). Sustainability Practices and Financial Performance: An empirical evidence from Indonesia,.International Conference on Trends in Economics, Humanities and Management. (ICTEHM'14) Aug 13-14. 2014. Pattaya (Thailand), 11-15.

Marwah, A.K., Thakur, G., \& Gupta, R.C. (2014), A Confirmatory Study of Supply Chain performance and Competitiveness of Indian Manufacturing Organization. International Journal of Quality Research, 8 (1), 23-38.

Mitra, P.K. (2012). Sustainability Reporting Practices in India: Its problems and prospects. International Journal of Marketing, Financial Services and Marketing Research, 1 (5), 109-115.

Millar, C.C.J.M., Eldomiaty, T.I., Choi, C.J., \& Hilton, B. (2005). Corporate governance and institutional transparency in emerging markets. Journal Business Ethics, 59 (1-2), 163-174.

Makori, D.M. (2013). Environment Accounting and Firm Profitability: An empirical analysis of selected firms listed in Bombay Stock Exchange India. International Journal of Humanities and Social Science, 3 (18), 248-256.

Michelon, G., \& Parbonetti, A. (2012). The effect of corporate governance on sustainability disclosure. Journal of Management - Governance, 16 (3), 477-509.

O'Donovan, G. (2002). Environmental disclosures in the annual report: Extending the applicability and predictive power of legitimacy theory. Accounting, Auditing \& Accountability Journal, 15 (3), 344-371.

Prasad, B.D. (2008). Content Analysis: A
Method of Social Science Research CSS. 1-20. New Delhi: Rawat, 173-193.

Parsa, S., \& Kouhy, R. (2008). Social Reporting by Companies Listed on the Alternative Investment Market. Journal of Business Ethics, 79 (3), 345-360.

Ullmann, A.A. (1985). Data in search of a theory, a critical examination of the relationships among social performance, social disclosure, and economic performance of US firms. The Academy of Management Review, 10 (3), 540-557.

Van der Laan Smith, J, Adhikari, A., \& Tondkar, R.H. (2005). Exploring differences in social disclosure internationally: A stakeholder perspective. Journal of Accounting \& Public Policy, 24 (2), 123151.

Wallace, R.S.O., Naser, K., \& Mora, A. (1994). The Relationship between the Comprehensiveness of Corporate Annual Reports and Firm Characteristics in Spain. Accounting and Business Research, 25 (97), 41-53.

Yao, S., Wang, J., \& Song, L. (2011). Determinants of social responsibility disclosure by Chinese firms. The China Policy Institute School of Contemporary Chinese Studies at The University of Nottingham, 1-30. 